\title{
SEROPREVALENCE AND RISK FACTORS ASSOCIATED TO NEOSPORA CANINUM IN FEMALE BOVINES FROM THE WESTERN SÃO PAULO STATE, BRAZIL
}

\author{
D.M. Aguiar ${ }^{1}$, D.P. Lacerda ${ }^{2}$, R.C. Orlandelli ${ }^{3}$, A.O. Medina ${ }^{3}$, \\ S.S. Azevedo ${ }^{3}$, L.H. Okuda ${ }^{4}$, V. Castro ${ }^{4}$, M.E. Genovez ${ }^{4}$, E.M. Pituco ${ }^{4}$
}

${ }^{1}$ Universidade Federal de Mato Grosso, Faculdade de Agronomia e Medicina Veterinária, Departamento de Clinica Médica Veterinária, Av. Fernando Correa da Costa, 2367, CEP 78060-900, Cuiabá, MT, Brasil. E-mail: danmoura@ufmt.br

\begin{abstract}
The prevalence of anti-Neospora caninum antibodies was evaluated in 1104 cows from 118 farms in the Western region of São Paulo State, Brazil, using indirect immunofluorescence antibody assay. Sixty-five (55.0\%; CI 95\%: 46.0-63.8\%) farms showed at least one seropositive animal. Prevalence over 10\% was observed in 33 farms (28.0\%; CI 95\%: 20.4-36.5\%), and over $20 \%$ in 18 farms (15.2\%; CI 95\%: 9.5-22.6\%). Prevalence of animals showed 120 (10.9\%) positive females (IFAT $\geq 1: 100$ ). The positivity in the farms showed significant association with farms producing more than 50 liters per day. Infection caused by the protozoan N. caninum occurs in the Western region of the state of São Paulo, and although no differences were observed either in relation to the production type or management practices, greater milk yield was related to greater prevalence of infection.
\end{abstract}

KEY WORDS: Neospora caninum, seroprevalence, epidemiology, bovine, Brazil.

\section{RESUMO}

SOROPREVALÊNCIA E FATORES DE RISCO ASSOCIADOS A NEOSPORA CANINUM EM FÊMEAS BOVINAS DO OESTE DO ESTADO DE SÃO PAULO, BRASIL. A prevalência de anticorpos anti-Neospora caninum foi avaliada em 1104 vacas de 118 fazendas da região oeste do Estado de São Paulo, Brasil, usando a Reação de Imunofluorescência Indireta. Sessenta e cinco (55,0\% ; IC 95\%: 46,0-63,8\%) fazendas apresentaram pelo menos um animal soropositivo. Prevalência acima de 10\% foi observada em 33 fazendas (28,0\%; IC 95\%: 20,4-36,5\%), e acima de 20\% em 18 (15,2\%; IC 95\%: 9,5-22,6\%). A prevalência de animais foi de 10,9\%, sendo 120 vacas positivas (RIFI $\geq 1: 100)$. Observou-se associação significativa entre a presença de animais positivos e fazendas com produção leiteira acima de 50 litros por dia. Infecção causada por N. caninum ocorre na região oeste do Estado de São Paulo, mesmo não tendo sido observada relação entre animais soropositivos e práticas de manejo, nas fazendas com alta produção leiteira foram observadas as maiores prevalências de infecção.

PALAVRAS-CHAVE: Neospora caninum, soroprevalência, epidemiologia, bovinos, Brasil.

\section{INTRODUCTION}

Neospora caninum is a protozoan first identified in dogs affected by encephalitis and myositis. It is an important cause of abortion in cattle, and may also infect other animals such as horses, goats, sheep, and deer (Dubey, 2003). The life cycle of N. caninum was described in 1998, when it was demonstrated that domestic dogs (Canis lupus familiaris) are definitive hosts of the agent, shedding oocysts in feces
(McAllister etal., 1998). Gondim et al. (2004) showed that coyotes (C. l. latrans) also shed the oocysts in feces and recently KING et al. (2010) found dingoes (C. l. dingo) shedding oocysts after being fed with infected bovine tissues. Cattle are infected through the ingestion of sporulated oocysts (DE MAREZ et al., 1999) whereas the existence of seropositive bovine populations (represented by congenitally infected females) also increases the risk of future losses caused by reproductive disorders associated to N. caninum.

${ }^{2}$ Polo Regional da Alta Sorocabana, Presidente Prudente, SP, Brasil.

${ }^{3}$ Universidade Federal de Campina Grande, Centro de Saúde e Tecnologia Rural, Unidade Acadêmica de Medicina Veterinária, Patos, PB, Brasil.

${ }^{4}$ Instituto Biológico, Centro de Pesquisa e Desenvolvimento de Sanidade Animal, São Paulo, SP, Brasil. 
In Brazil, N. caninum infection was first diagnosed by Gondim et al. (1999), using immunohistochemistry (IHC) and serology in a single naturally infected fetus in the State of São Paulo. PESCADOR et al. (2007), in a study of 258 bovine fetuses in Rio Grande do Sul State between 1999 and 2005, concluded that $N$. caninum infection may be an important cause of abortion, because the parasite was detected by IHC in $21.3 \%$ of fetuses presenting lesions. Prevalence of infection in Brazil ranges from 7 to $42 \%$ (Costa et al., 2001; LOCATELLI-DitTRICH et al., 2001) among regions and depending on the types of herds (dairy, beef, or mixed production). Risk factors to presence of antibodies against $N$. caninum in cattle have been reported in studies performed all over Brazil. Farm area (hectares), number of cows, production type (beef, dairy cattle), age of cattle, feeding silage and or concentrate produced on the farm, and presence and number of dogs have been associated with $N$. caninum prevalence in Northern and Southern areas of Brazil (GUIMARÃES JunIOR. et al., 2004; AgUiAr et al., 2006; CorbelLini et al., 2006), while these data have not yet been collected in the State of São Paulo, Brazil.

In this study were determined the prevalence and possible risk factors for $N$. caninum infection in the Western region of the State of São Paulo. Cattle breeding in this region yield $20 \%$ of the total beef and dairy income of the state. In addition, the Western region of the state is responsible for approximately US\$ 7.2 million in beef and dairy production (IEA, 2006).

\section{MATERIAL AND METHODS}

\section{Region studied and sampling procedures}

This study was done in the Western region of the State of São Paulo. Sampling procedures were based on data previously collected for a seroepidemiological study for bovine brucellosis in the state, as part of the National Program for the Control and Eradication of Bovine Brucellosis and Tuberculosis [Programa Nacional de Controle e Erradicação da Brucelose e Tuberculose Bovina-PNCEBT] (DiAs et al., 2009). The studied area included municipalities located in three micro-regions that cover the whole Western São Paulo Production Area. These areas are PresidentePrudente $\left(22^{\circ} 7^{\prime} \mathrm{S}, 51^{\circ} 22^{\prime} \mathrm{W}\right)$ and Presidente Venceslau ( $21^{\circ} 52^{\prime} \mathrm{S}, 51^{\circ} 50^{\prime} \mathrm{W}$ ) (Alta Sorocabana Region); Dracena $\left(21^{\circ} 28 \mathrm{~S}, 51^{\circ} 31^{\prime} \mathrm{W}\right)$ and Tupã $\left(21^{\circ}\right.$ $\left.56^{\prime} \mathrm{S}, 50^{\circ} 30^{\prime} \mathrm{W}\right)$ (Alta Paulista Region); Andradina $\left(20^{\circ} 53^{\prime} \mathrm{S}, 51^{\circ} 22^{\prime} \mathrm{W}\right)$ and Araçatuba $\left(21^{\circ} 12^{\prime} \mathrm{S} 50^{\circ} 25^{\prime}\right.$ W) (Extreme West Region). The sites were chosen considering the similarities among production systems, management practices, production goals, herd size, and trade systems. The Western region is characterized by a subtropical climate where the predominant vegetation is savannah and rain forest, although the vegetation in region has been almost devastated by agribusiness.

The primary sampling unit was determined by randomly picking farms that conducted breeding activities and that were registered in the São Paulo Agriculture Office. According to data obtained by the Technical Assistance Coordination (Coordenadoria de Assistência Técnica-CATI) in this production area in 2001, breeding activities occurred on 29,091 farms, where there were 1,333,508 bovine females over 24 months. The number of farms to be evaluated to obtain a representative sample was determined by the software EpiInfo 6.04 using an estimated prevalence of $20 \%$, absolute error of $10 \%$, and confidence interval of $95 \%$.

The serum samples were obtained from a previous study (DiAs et al., 2009) that aimed to estimate the brucellosis prevalence among cows over two years of age (adult cows). The number of tested animals was determined by aggregated sensibility and sensitivity of the diagnostic protocol (screening by 2-mercaptoethanol and complement fixation test as confirmatory), 95\% and $99.5 \%$, respectively (FLETCHER, 1998). Using an expected prevalence of $20 \%$, simulations on Herdacc software 3.0 were made to establish the size of the secondary sample (number of animals to be sampled in each visited farm). Simulations expected at reach at least $90 \%$ aggregated sensibility and sensitivity, according to MARTIN et al. (1992) and JORDAN (1996). This indicated that in herds of up to 100 adult cows, 10 cows should be sampled and in herds over 100 adult cows, 15 cows should be sampled. In herds with less than 10 adult cows, all animals were sampled. When at least one animal was positive, the farm was classified as positive (DonALD et al., 1994).

\section{Collection of blood samples}

Blood samples were collected in October and November of 2001. Samples were kept at room temperature $\left(20^{\circ} \mathrm{C}\right)$ in the tubes until clotting. Serum samples were stored at $-20^{\circ} \mathrm{C}$ until analysis.

\section{Indirect fluorescence antibody test}

Serum samples were analyzed by Indirect Fluorescence Antibody Test (IFAT) using an initial dilution of 1:100 in phosphate buffer $\left(0.0084 \mathrm{MNa}_{2} \mathrm{HPO}_{4}\right.$, $0.0018 \mathrm{MNaH}_{2} \mathrm{PO}_{4^{\prime}}$ and $\left.0.147 \mathrm{MNaCl}\right), \mathrm{pH} 7.2$, added to $1 \%$ bovine serum albumin (MINERVINO et al., 2008), using a rabbit anti-bovine $\operatorname{IgG}$ conjugate labeled with fluorescein isothiocyanate (SIGMA F-7887). 
Samples considered positive in the initial dilution were submitted to successive two-fold serial dilutions to yield the final titer. Each set of slides included positive and negative control sera.

\section{Questionnaire}

At the time of farm visits, a questionnaire was administered to assess the presence or absence of farming practices and local conditions that may represent risk factors for $N$. caninum infection. These variables included the type of production (beef, dairy, mixed); housing conditions (confinement, semi-confinement, or free range production); number of cows; mode of milking (manual, mechanical using a portable milking machine, or mechanical in a milking parlor); milk production yield in liters per day; presence of other animal species on the farm; occurrence of abortion in the previous 12 months; exchange of cows for breeding; renting or sharing of pastures; and the use of separate enclosures for cows pre- or post-partum.

\section{Calculation of prevalence and statistical analysis}

Prevalence per farm was calculated using a confidence interval of $95 \%$. As farms with different herd sizes were evaluated, the overall prevalence estimate was adjusted based on herd size of each analyzed farm (THRUSFIELD, 1995). These calculations were conducted using EpiInfo 6.04 software.

Differentanalyses wereperformed toverify possible risk factors; in these analyses three prevalence values were considered. Variables were evaluated in farms with at least one seropositive cow, and in farms with at least $10 \%$ and $20 \%$ of seropositive cattle. The association between environmental variables and serology results was calculated through univariate and multivariate analyses (HOSMER and LEMESHOW, 1989). Univariate analysis was performed using the Chi-square test $\left(\chi^{2}\right)$ and, when necessary, Fisher's exact test, with confidence intervals of $95 \%$. Multivariate analysis was based on logistic regression in a model involving those variables that showed $P \leq$ 0.20 in the association test. Analyses were done using EpiInfo 6.04 and SPSS for Windows.

\section{RESULTS}

Samples were collected from 118 farms, 60 of which $(50.8 \%)$ were dedicated to mixed production (dairy and beef), $34(28.8 \%)$ to beef production, and $23(19.5 \%)$ to dairy. One farm $(0.9 \%)$ was not classified in any of the above categories. Samples were collected from 1104 cows, in herds that ranged from one to 1300 cows per farm (median of 24 cows). Of the total, dairy cattle comprised 175 (15.9\%) cows, beef cattle $348(31.5 \%)$ cows, and mixed cattle 580 $(52.6 \%)$ cows. One cow $(0.1 \%)$ was not classified in any of the above categories.

\section{Serological analyses}

Of the 118 analyzed farms, 65 showed at least one positive animal, resulting in a prevalence of positive farms of $55.0 \%$ (CI95\%: 46.0-63.8\%). Prevalence over $10 \%$ was observed in 33 farms (28.0\%; CI 95\%: $20.4-$ $36.5 \%)$, and over $20 \%$ in 18 farms (15.2\%; CI 95\%: 9.5-22.6\%). Serum samples from 120 of 1104 animals were positive (IFAT $\geq 100$ ) with a prevalence of $10.9 \%$. The adjusted prevalence for infected animals was estimated as $10.5 \%$ (CI 95\%; 7.3-15.0\%). Antibody titers varied from 100 to 12,800 (Table 1). The Table 2 shows the number of positive farms and positive cows by region. Beef, dairy, and mixed farms had similar $(\mathrm{P}>0.05)$ prevalence values for anti-N. caninum antibodies, when analyzed in different levels of prevalence per farm (at least one, $10 \%$, and $20 \%$ of positive cows). No statistical differences ( $\mathrm{P}>$ 0.05 ) were found between production systems, with values of $13.7 \%$ for dairy cows, $8.6 \%$ for beef cows, and $11.3 \%$ for mixed cows (Table 3 ).

Table 1 - Distribution of anti-Neospora caninum antibody titers, determined by Indirect Fluorescence Antibody Test (IFAT), in 120 positive cows from Western São PauloState.

\begin{tabular}{lcc}
\hline \multirow{2}{*}{ Titer } & \multicolumn{2}{c}{ Positive samples } \\
\cline { 2 - 3 } & Number & $\%$ \\
\hline 100 & 55 & 45.8 \\
200 & 16 & 13.4 \\
400 & 16 & 13.4 \\
800 & 12 & 10.0 \\
1600 & 06 & 5.0 \\
3200 & 09 & 7.5 \\
6400 & 02 & 1.6 \\
12800 & 04 & 3.3 \\
\hline Total & 120 & 100 \\
\hline
\end{tabular}

\section{Uni- and multi-variate analyses}

Results of the association between positive farms and the variables studied are shown in Table 4. Variables that showed $\mathrm{P}<0.20$ in the initial analysis were analyzed by logistic regression. According to the final model, farms that yielded more than 50 liters per day were more likely to show animals positive for N. caninum when at least one and $10 \%$ of cows were seropositive per farm (Table 5). 
Table 2 - Number of farms and examined cows, positivity, and occurrence (\%) of antibody anti-Neospora caninum per Micro-region in Western São Paulo State, Brazil.

\begin{tabular}{lcccccc}
\hline Micro-regions & \multicolumn{3}{c}{ Farms } & \multicolumn{3}{c}{ Cows } \\
\cline { 2 - 7 } & Sampled & Positive & $\%^{*}$ & Sampled & Positive & $\%^{*}$ \\
\hline Extreme west & 26 & 12 & $46.1^{\text {a }}$ & 240 & 17 & $7.1^{\text {a }}$ \\
Alta Paulista & 49 & 23 & $46.9^{\text {a.b }}$ & 425 & 46 & $10.8^{\text {a.c }}$ \\
Alta Sorocabana & 43 & 30 & $69.7^{\text {a.c }}$ & 439 & 57 & $13.0^{\text {b.c }}$ \\
\hline Totals for all regions & 118 & 65 & $55.0^{\text {s }}$ & 1104 & 120 & $10.9^{\mathrm{F}}$ \\
\hline
\end{tabular}

${ }^{*}$ Columns showing different letters indicate significant difference $(P \leq 0.05)$.

§ Observed prevalence equal to 55.0\% (CI95\%: 46.0-63.8\%).

F Prevalence of $10.9 \%$; adjusted prevalence of $10.5 \%$ (CI 95\%; $7.3 \%-15.0 \%$ ).

Table 3 - Prevalence of anti-Neospora caninum antibodies in farms and cows stratified by production type in Western of São Paulo State.

\begin{tabular}{|c|c|c|c|c|c|c|}
\hline \multirow{3}{*}{ Production type* } & \multicolumn{4}{|c|}{ Farms $^{\mathrm{a}}$} & \multicolumn{2}{|c|}{ Cows $^{a}$} \\
\hline & \multirow{2}{*}{ Sampled } & \multicolumn{3}{|c|}{ Prevalence of positive (\%) } & \multirow{2}{*}{ Sampled } & \multirow{2}{*}{$\begin{array}{c}\text { Positive } \\
(\%)\end{array}$} \\
\hline & & At least one & $10 \%$ & $20 \%$ & & \\
\hline Dairy & 23 & $14(60.8)$ & $08(34.7)$ & 03 (13.1) & 175 & $24(13.7)$ \\
\hline Beef & 34 & $17(50.0)$ & $08(23.5)$ & $06(17.6)$ & 348 & $30(8.6)$ \\
\hline Mixed production & 60 & $34(56.6)$ & $17(28.3)$ & $09(15.0)$ & 580 & $66(11.3)$ \\
\hline Total* & $118^{*}$ & $65(55.0)^{b}$ & $33(28.0)^{c}$ & $18(15.2)^{\mathrm{d}}$ & 1103 & 120 \\
\hline
\end{tabular}

* One farm and cow could not be classified in any of the categories

${ }^{a}$ Different values between proportions $=\mathrm{P}>0.05$

${ }^{\text {b }}$ CI 95\%: 46.0-63.8\%

c CI 95\%: 20.4-36.5\%

d CI 95\%: 9.5-22.6\%

\section{DISCUSSION}

The region here studied is an important cattle production area, not only for the State of São Paulo, but for the Brazil as a whole. Approximately, 5 in every 10 farms showed at least one seropositive cow to N. caninum, illustrating the wide dissemination of the parasite in the region. The results showed that $N$. caninum seroprevalence in cows $(10.5 \%)$ is close to that observed in other regions of São Paulo and Brazil (Hasegawa et al., 2004; Ragozo et al., 2004; Aguiar et al., 2006; Melo et al., 2006). However, results obtained in different studies should be critically compared due to the varying diagnostic methods and cutoff values used to detect anti-N. caninum antibodies.

Variations in prevalence were observed among regions. Alta Sorocabana region showed the greatest frequency of seropositive cows, as well as the greatest number of farms with seropositive animals. The two Municipalities included in this region (Presidente Prudente and Presidente Venceslau) are located on the border of State of São Paulo with State of Mato Grosso (West-central region) and State of Paraná (South region). This area is characterized by the presence of the beef finishing sector and the main slaughterhouses of the Western region of the São
Paulo State, which leads to intense movement of animals on farms, increasing the chances of finding the highest prevalence rates.

In an attempt to understand the epidemiology of $N$. caninum in cattle in the region, an evaluation considering three hypotheses of prevalence in farms (at least one, $10 \%$, and $20 \%$ seropositive cows per farm) was performed. However, no significant differences in prevalence $(P>0.05)$ among farms or breeding systems (beef, dairy, and mixed production cattle) were observed. These results show a high spread of $N$. caninum in the region, occurring in the same proportion in all production systems. In the brazilian central region, Melo et al. (2006) in the State of Goiás and OsHiro et al. (2007) in the State of Mato Grosso do Sul, also found no difference among cattle production systems (beef, dairy, and mixed exploration) and N. caninum prevalence in cattle.

In the Northern Amazon region, State of Pará, Minervino et al. (2008), also observed similar results among production systems; however AGUIAR et al. (2006) in the Western Amazon region, State of Rondônia, detected higher prevalence in beef herds than in dairy and mixed production. The difference observed between these studies may be associated with variations relating to the environment or breeding practices adopted in each region. 
Aguiar et al. (2006) associated herd size as a risk factor to the presence of seropositive cows on farms, collaborating with the occurrence of $N$. caninum in beef cattle. Beef herds in the brazilian North region are characterized by breeding in large herds, and cattle are kept in free-range management; contrasting with the present region, where beef cattle are close monitored and the numbers of cattle and pasture areas are smaller. In the present study none of the management practices (production type, number of cows, and housing conditions) were associated to $N$. caninum seropositivity on farms.

Logistic regression showed that farms yielding more than $50 \mathrm{~L}$ of milk a day are at greater risk for showing positive animals. This value (50 L) was stipulated considering median values of milk production per farm. Some mixed production farms were also included in the variable concerning milk production (23 dairy farms and 52 mixed farms analyzed). Dairy farms have a higher milk yield per day and mixed farms tend to have several lactating animals. Although there were no significant differences in relation to the type of production, dairy and mixed production farms showed greater frequency of animals with anti- $N$. caninum antibodies. These results may be explained by the more intensive practices used in dairy cattle management, and by the maintenance of older animals in the herd, increasing both environmental exposure to N. caninum and the chance of detecting positive animals (GUIMARÃES JUNIOR et al., 2004).

Other analyzed variables did not seem to be associated with the presence of anti-N. caninum antibodies. However, presence of other domestic species and flooded areas in the farms were selected for the final logistic regression model. Farms with $10 \%$ of prevalence with no dogs showed more frequency of seropositive cows (Table5). According to MCAllister et al., (1998), dogs are definitive hosts of $N$. caninum and their presence is considered a risk factor for seropositivity in cattle by many authors (MAINAR JAIME et al., 1999; OTRANTO et al., 2003; Schares et al., 2004; Corbellini et al., 2006). Although the absence of dogs in farms suggests the possible occurrence of vertical transmission, this could not be confirmed, whereas the practice of exchanging cows for breeding observed in many farms could be an important factor related to higher occurrence, as cows may have become seropositive previously (Table 4).

Table 4 - Results of variables evaluated in the questionnaire completed by farms in Western São Paulo State, according different prevalence values per farm: at least one seropositive cow; $10 \%$ seropositive cows; and $20 \%$ seropositive cows.

\begin{tabular}{|c|c|c|c|c|c|c|c|}
\hline \multirow{4}{*}{ Variables } & \multicolumn{7}{|c|}{ Number of farms } \\
\hline & \multirow{3}{*}{ Presence } & \multicolumn{6}{|c|}{ Positive } \\
\hline & & \multicolumn{2}{|c|}{ At least one } & \multicolumn{2}{|c|}{$10 \%$} & \multicolumn{2}{|c|}{$20 \%$} \\
\hline & & $\%$ & $P$ & $\%$ & $P$ & $\%$ & $P$ \\
\hline \multicolumn{8}{|l|}{ Housing conditions } \\
\hline Confinement & 03 & 66.6 & 1.00 & 33.3 & 1.00 & 33.3 & 0.39 \\
\hline Semi-confinement & 06 & 33.3 & 0.40 & 33.3 & 1.00 & 0 & 0.59 \\
\hline Free range & 108 & 56.5 & 0.50 & 27.8 & 0.70 & 15.7 & 1.00 \\
\hline \multicolumn{8}{|l|}{ Mode of milking } \\
\hline Manual & 69 & 60.0 & 0.68 & 27.5 & 1.00 & 17.4 & 1.00 \\
\hline Portable milking machine & 04 & 25.0 & 0.30 & 25.0 & 1.00 & 0 & 1.00 \\
\hline Milking parlor & 02 & 100.0 & 0.50 & 0 & 1.00 & 50.0 & 0.31 \\
\hline Yield in liters per day $(\geq 50 \mathrm{~L})$ & 38 & 73.7 & 0.00 & 39.5 & 0.01 & 21.5 & 0.39 \\
\hline Number of cows ( $\geq 24$ cows) & 60 & 60.0 & 0.28 & 35.0 & 0.00 & 13.3 & 0.61 \\
\hline \multicolumn{8}{|l|}{ Presence of other animal species } \\
\hline Dog & 90 & 50.0 & 0.04 & 21.1 & 0.00 & 17.7 & 0.23 \\
\hline Horse & 99 & 55.5 & 0.81 & 30.3 & 0.19 & 16.1 & 0.73 \\
\hline Swine & 51 & 53.0 & 0.68 & 21.5 & 0.17 & 21.5 & 0.09 \\
\hline Poultry & 76 & 54.0 & 0.73 & 22.3 & 0.06 & 19.7 & 0.12 \\
\hline Sheep & 25 & 44.0 & 0.21 & 08 & 0.01 & 20.0 & 0.53 \\
\hline Cat & 65 & 48.0 & 0.07 & 23.1 & 0.19 & 13.8 & 0.63 \\
\hline Abortion in the previous 12 months & 07 & 71.5 & 0.45 & 42.8 & 0.38 & 28.5 & 0.33 \\
\hline Exchange of cows for breeding & 51 & 60.7 & 0.52 & 29.5 & 0.96 & 19.6 & 0.33 \\
\hline Renting of pastures & 17 & 53.0 & 0.63 & 17.6 & 0.38 & 23.5 & 0.29 \\
\hline Sharing of pastures & 09 & 55.5 & 1.00 & 22.2 & 1.00 & 22.2 & 0.62 \\
\hline Areas for cows pre- or post-partum & 37 & 56.7 & 0.81 & 27.0 & 0.81 & 16.2 & 0.74 \\
\hline Flooded areas & 18 & 27.7 & 0.01 & 11.1 & 0.14 & 11.1 & 0.73 \\
\hline
\end{tabular}


Table 5 - Results of univariate and multivariate analyses of association between variables and farms with at least one and $10 \%$ of cows seropositive to Neospora caninum antibodies in Western São Paulo State.

\begin{tabular}{|c|c|c|c|c|c|c|}
\hline \multirow{2}{*}{ Variables analyzed } & \multicolumn{2}{|c|}{ Number of farms } & \multicolumn{2}{|c|}{ Univariate analysis } & \multicolumn{2}{|c|}{ Multivariate analysis } \\
\hline & Analyzed & Positive & $x^{2}$ & $P$ & $P$ & Odds (CI 95\%) \\
\hline \multicolumn{7}{|c|}{ Farms with at least one seropositive cow } \\
\hline \multicolumn{7}{|l|}{ Milk yield per day } \\
\hline$<50 \mathrm{~L}$ & 37 & $16(43.3)$ & & & & \\
\hline$\geq 50 \mathrm{~L}$ & 38 & $28(73.7)$ & 7.1 & 0.007 & 0.008 & $3.800(1.43-10.55$ \\
\hline \multicolumn{7}{|c|}{ Farms with at least $10 \%$ seropositive cows } \\
\hline \multicolumn{7}{|l|}{ Milk yield per day } \\
\hline$<50 \mathrm{~L}$ & 37 & $05(13.5)$ & & & & \\
\hline$\geq 50 \mathrm{~L}$ & 38 & $15(39.5$ & 6.4 & 0.01 & 0.008 & $5.06(1.51-16.90)$ \\
\hline \multicolumn{7}{|l|}{ Presence of dogs } \\
\hline No & 28 & $14(50.0)$ & & & & \\
\hline Yes & 90 & $19(21.1)$ & 8.8 & 0.003 & 0.019 & $0.20(0.73-079$ \\
\hline
\end{tabular}

Presence of horses, swine, sheep, poultry, and cats were evaluated by logistic regression, but failed as risk factors. All species detected in farms are considered intermediate hosts to $N$. caninum (DubeY et al., 2007) and their presence suggest an alternative route for $N$. caninum infection to carnivorous host. Furthermore, COSTA et al. (2008) showed the first confirmation of natural N. caninum infection in chickens from Brazil. Chickens are cosmopolitan animals that may be consumed by dogs. OTRANTO et al. (2003) in Italy, observed that seropositivity to N. caninum in cattle was associated with the presence of poultry on farms. This data suggests that further studies in Brazil need to be done with these species to clarify the involvement with $N$. caninum epidemiology.

Infection caused by the protozoan N. caninum occurs in the Western region of the State of São Paulo, and although no differences were observed either in relation to the production type or management practices. Farms with greater milk yield presented greater prevalence of infection.

\section{ACKNOWLEDGEMENTS}

To Fundação de Amparo à Pesquisa do Estado deSão Paulo for the financial resources for the study (FAPESP 06/57743-1), and for scholarship to D.P. Lacerda (FAPESP 2007/54591-9) and technical training grant to R.C. Orlandelli (FAPESP 08/02768-5).

\section{REFERENCES}

AGUIAR, D.M.; CAVALCANTE, G.T.; RODRIGUES, A.A.R.; LABRUNA, M.B.; CAMARGO, L.M.A.; CAMARGO, E.P.; GENNARI, S.M. Prevalence of anti-Neospora caninum antibodies in cattle and dogs from Western Amazon, Brazil, in association with some possible risk factors. Veterinary Parasitology, v.142, p.71-77, 2006.
CORBELLINI, L.G.; SMITH, D.R.; PESCADOR, C.A.; SCHMITZ, M.; CORREA, A.; STEFFEN, D.J.; DRIEMEIER, D. Herd-level risk factors for Neospora caninum seroprevalence in dairy farms in southern Brazil. Preventive Veterinary Medicine, v.74, p.130-141, 2006.

COSTA, G.H.N.; CABRAL, D.D.; VARANDAS, N.P.; SOBRAL, E.A.; BORGES, F.A.; CASTAGNOLLI, K.L. Freqüência de anticorpos anti-Neospora caninum e antiToxoplasma gondii em soros de bovinos pertencentes aos Estados de São Paulo e Minas Gerais. Semina Ciências Agrárias, v.22, p.57-62, 2001.

COSTA, K.S.; SANTOS, S.L.; UZÊDA, R.S.; PINHEIRO, A.M.; ALMEIDA, M.A.O.; ARAÚJO, F.R.; MCALLISTER, M.M.; GONDIM, L.F.P. Chickens (Gallus domesticus) are natural intermediate hosts of Neospora caninum. International Journal for Parasitology, v.38, p.157-159, 2008.

DE MAREZ, T.; LIDDELL, S.; DUBEY, J.P.; JENKINS, M.C.; GASBARRE, L. Oral infection of calves with Neospora caninum oocysts from dogs: humoral and cellular immune responses. International Journal of Parasitology, v.29, p.1647-1657, 1999.

DIAS, R.A.; GONÇALVES, V.S.P.; FIGUEIREDO, V.C.F.; LÔBO, J.R.; LIMA, Z.M.B.; PAULIN, L.M.S.; GUNNEWIEK, M.F.K.; AMAKU, M.; FERREIRA NETO, J.S.; FERREIRA, F. Situação epidemiológica da brucelose bovina no Estado de São Paulo. Arquivos Brasileiros de Medicina Veterinária e Zootecnia, v.61, p.118-125, 2009. Suplemento 1.

DONALD, A.W.; GARDNER, I.A.; WIGGINS, A.D. Cutoff points for aggregate herd testing in the presence of disease clustering and correlation of test errors. Preventive Veterinary Medicine, v.19, p.167-187, 1994.

DUBEY, J.P.; SCHARES, G.; ORTEGA-MORA, L.M. Epidemiology and Control of Neosporosis and Neospora caninum. Clinical Microbiology Review, v.20, p.323-367, 2007. 
DUBEY, J.P. Review of Neospora caninum and neosporosis in animals. Korean Journal of Parasitology, v.41, p.1-16, 2003.

FLETCHER, R.H.; FLETCHER, S.W.; WAGNER, E.H. Clinical epidemiology: The essentials. 2.ed. Baltimore: Williams \& Wilkins, 1998. 246p.

GONDIM, L.F.P.; MCALLISTER, M.M.; PITT, W.C.; ZEMLICKA, D.E. Coyotes (Canis latrans) are definitive hosts of Neospora caninum. International Journal of Parasitology, v.34, p.159-161, 2004.

GONDIM, L.F.P.; SARTOR, I.F.; HASEGAWA, M.; YAMANE, I. Seroprevalence of Neospora caninum in dairy cattle in Bahia, Brazil. Veterinary Parasitology, v.86, p.71-75, 1999.

GUIMARÃES JUNIOR, J.S.; SOUZA, S.L.; BERGAMASCHI, D.P.; GENNARI, S.M. Prevalence of Neospora caninum antibodies and factors associated with their presence in dairy cattle of the north of Parana state, Brazil. Veterinary Parasitology, v.124, p.1-8, 2004.

HASEGAWA, M.Y.; SARTOR, I.F.; CANAVESSI, A.M.O.; PINCKNEY, R.D. Ocorrência de anticorpos anti-Neospora caninum em bovinos de corte e em cães rurais da região de Avaré, Estado de São Paulo, Brasil. Semina Ciências Agrárias, v.25, p.45-50, 2004.

HOSMER JUNIOR, D.W.; LEMESHOW, S. Applied logistic regression. New York: Wiley, 1989. 307p.

IEA. Instituto de Economia Agrícola. Área e valor de produção dos principais produtos da agropecuária. (Banco de Dados). Disponível em: <http:/ /www.iea.sp.gov.br/ out/banco/menu.php>. Acesso em: out. 2006.

JORDAN, D. Aggregate testing for the evaluation of Johne's disease herd status. Australian Veterinary Journal, v.73, p.16-19, 1996.

KING, J.S.; SLAPETA, J.; JENKINS, D.J.; AL-QASSAB, S.E.; ELLIS, J.T.; WINDSOR PA. Australian dingoes are definitive hosts of Neospora caninum. International Journal of Parasitology, 2010. [No prelo].

LOCATELLI-DITTRICH, R.; THOMAS-SOCCOL, V.; RICHARTZ, R.R.T.B.; GASINO-JOINEAU, M.E.; PINCKNEY, R.D. Serological diagnosis of neosporosis in a herd of dairy cattle in southern Brazil. Journal of Parasitology, v.87, p.1493-1494, 2001.

MAINAR-JAIME, R.C.; THURMOND, M.C.; BERZALHERRANZ, B.; HIETALA, S.K. Seroprevalence of Neospora caninum and abortion in dairy cows in northern Spain. Veterinary Record, v.145, p.72-75, 1999.

MARTIN, S.W.; SHOUKRI, M.; THORBURN, M.A. Evaluating the health status of herds based on tests applied to individuals. Preventive Veterinary Medicine, v.14, p.33-43, 1992.

McALLISTER, M.M.; DUBEY, J.P.; LINDSAY, D.S.; JOLLEY, W.R.; WILLS, R.A.; MCGUIRE, A.M. Dogs are definitive hosts of Neospora caninum. International Journal of Parasitology, v.28, p.1473-1479, 1998.

MELO, D.P.; SILVA, A.C.; ORTEGA-MORA, L.M.; BASTOS, S.A.; BOAVENTURA, C.M. Prevalence of antibodies anti-Neospora caninum in bovines from Anápolis and Goiânia microregions, Goiás, Brazil. Revista Brasileira de Parasitologia Veterinária, v.15, p.105-109, 2006.

MINERVINO, A.H.; RAGOZO, A.M.; MONTEIRO, R.M.; ORTOLANI, E.L.; GENNARI, S.M. Prevalence of Neospora caninum antibodies in cattle from Santarém, Pará, Brazil. Research in Veterinary Science, v.84, p.254-256, 2008.

OSHIRO, L.M.; MATOS, M.F.; OLIVEIRA, J.M.; MONTEIRO, L.A.; ANDREOTTI, R. Prevalence of anti-Neospora caninum antibodies in cattle from the state of Mato Grosso do Sul, Brazil. Revista Brasileira de Parasitologia Veterinária, v.16, p.133-138, 2007.

OTRANTO, D.; LLAZARI, A.; TESTINI, G.; TRAVERSA, D.; DI REGALBONO, A.F.; BADAN, M.; CAPELLI, $\mathrm{G}$. Seroprevalence and associated risk factors of neosporosis in beef and dairy cattle in Italy. Veterinary Parasitology, v.118, p.7-18, 2003.

PESCADOR, C.A.; CORBELLINI, L.G.; OLIVEIRA E.C.; RAYMUNDO, D.L.; DRIEMEIER, D. Histopathological and immunohistochemical aspects of Neospora caninum diagnosis in bovine aborted fetuses. Veterinary Parasitology, v.150, p.159-163, 2007.

RAGOZO, A.M.A.; PAULA, V.S.O.; SOUZA, S.L.P.; BERGSMASCHI, D.P.; GENNARI, S.M. Ocorrência de anticorpos anti-Neospora caninum em soros bovinos procedentes de seis estados brasileiros. Revista Brasileira de Parasitologia Veterinária, v.12, p.33-37, 2003.

SCHARES, G.; BÄRWALD, A.; STAUBACH, C.; ZILLER, M.; KLÖSS, D.; SCHRODER, R.; LABOHM, R.; DRÄGER, K.; FASEN, W.; HESS, R.G.; CONRATHS, F.J. Potential risk factors for bovine Neospora caninum infection in Germany are not under the control of the farmers. Parasitology, v.129, p.301-309, 2004.

THRUSFIELD, M. Veterinary epidemiology. 2.ed. Oxford: Blackwell Scientific Publication, 1995. 479p.

Recebido em $11 / 7 / 10$

Aceito em 24/4/11 